\title{
Kyrle's Disease in a Patient with Delusions of Parasitosis
}

\author{
M. TAMPA ${ }^{1}$, MARIA ISABELA SÂRBU ${ }^{2}$, CLARA MATEI $^{1}$, DANIELA E. MIHĂILĂ ${ }^{3}$, \\ T. D. POTECA ${ }^{3}$, SIMONA-ROXANA GEORGESCU ${ }^{1}$ \\ 1“"Carol Davila" University of Medicine and Pharmacy, Bucharest, Romania \\ "'Victor Babeş" Hospital of Infectious and Tropical Diseases, Dermatology Department, Bucharest, Romania \\ "Colentina" Clinical Hospital, General Surgery Department, Bucharest, Romania
}

\begin{abstract}
Acquired perforating disorders are a group of uncommon skin conditions characterized by transepidermal extrusion of altered dermal material, most often associated with diabetes mellitus and chronic kidney failure. Delusional parasitosis is a primary psychiatric disorder in which affected patients have fixed, false beliefs that their skin is infested by parasites, in the absence of any evidence supporting their statements.

A 69 year old malepatient addressed the Dermatology Department for a skin eruption consisting of multiple umbilicated keratotic papules with a generalized distribution. The patient believed that the lesions were produced by small parasites entering and exiting his skin. The histopathological examination confirmed the clinical diagnosis of Kyrle's disease. The psychiatric examination established the diagnosis of delusions of parasitosis.

This is the first reported case of Kyrle's disease associated with delusions of parasitosis. There is no evidence supporting the hypothesis that delusions of parasitosis might be a predisposing factor for Kyrle's disease. However, we believe that the pruritic dermatosis might have triggered the delusions of parasitosis due to the associated pruritus. On the other hand the constant excoriations and traumatizing of a skin prone to develop idiopathic Kyrle's disease in the attempt to remove the parasites prevented the complete resolution of the lesions.
\end{abstract}

Key words: Kyrle's disease, delusional parasitosis, psychiatric disorder, pruritus, Morgellons disease.

\section{INTRODUCTION}

Acquired perforating disorders are a group of uncommon skin conditions characterized by transepidermal extrusion of altered dermal material, often associated with diabetes mellitus and chronic renal failure [1-3].

Delusional parasitosis is a primary psychiatric disorder in which affected patients have fixed, false beliefs that their skin is infested by parasites, in the absence of evidence supporting their statements $[2,4]$.

\section{CASE REPORT}

A 69 year old male patient addressed the dermatology department for a skin eruption consisting of multiple umilicated keratotic papules with a generalized distribution. The lesions were moderately pruritic and had occurred 3 years before presentation. The patient believed that they were produced by small parasites entering and exiting his skin. He picked on skin lesions and collected debris from his skin, which he believed were parasites and their eggs, in a box. The patient had been treated for scabies with no clinical improvement. On clinical examination we noticed multiple umilicated keratotic follicular and perifollicular papules with individual central keratotic plug, with a generalized distribution, as well as multiple generalized shallow depressed scars, probably following resolution of the formerly described papules.

The complete blood count, biochemical tests, fasting blood glucose level and the glucose tolerance test were within normal range. Hepatitis B, C and HIV testing turned out negative. A psychiatric evaluation was recommended and the patient was diagnosed with delusions of parasitosis.

A biopsy was taken from one of the lesions (Figures 1,2) and confirmed the clinical suspicion of Kyrle's disease. He was treated with Clindamycin, antihistamines and tretinoin, with acceptable results. He was also referred to the psychiatric department for antipsychotic treatment. 

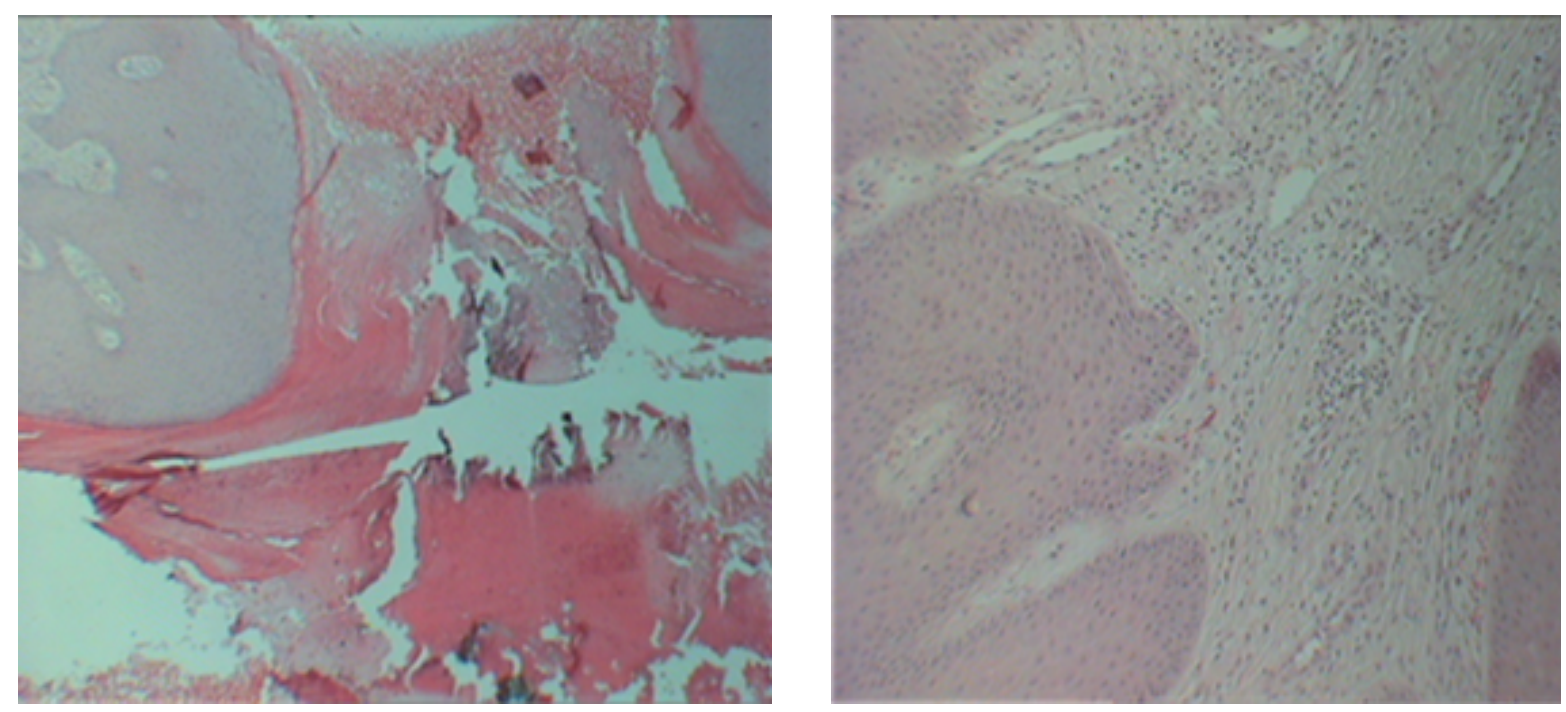

Figure 1 (left), Figure 2 (right). Histopathological examination. Transepidermal elimination of dermal material consisting of fibrous, leucocyte and keratin detritus through epidermal invaginations ( $\mathrm{H}$ and $\mathrm{E}, \mathrm{x}$ 10) (Figure 1), irregular acanthosis, papillomatosis and inflammatory infiltrate in the dermis ( $\mathrm{H}$ and $\mathrm{E}, \mathrm{x} 40)$ (Figure 2).

\section{DISCUSSION}

Kyrle's disease was described by Kyrle in 1916 as "hyperkeratosis follicularis et parafollicularis in cutem penetrans", and classified as a disorder of keratinization with follicular and parafollicular hyperkeratotic lesions $[5,6]$.

It usually occurs in adults aged between 30 and 50 years. It affects men and women with a similar frequency [7]. A study performed on patients with APD showed that $86.4 \%$ had at least one associated systemic disease, most commonly chronic renal failure $(72.7 \%)$ and diabetes mellitus $(50 \%)[1,8]$.

The etiology of the disease remains unknown but several hypotheses were proposed such as defective differentiation of the epidermis and the dermal-epidermal junction secondary to glycosylation processes [9], infectious etiology, probably anaerobic bacteria [10] and genetic etiology [11, 12].

The pathogenesis of the disease is unknown but superficial trauma is thought to be an inciting factor in patients susceptible to develop APD while vasculopathy and dermal deposits of exogenous materials seem to be predisposing factors [1].

The differential diagnosis includes prurigo nodularis, arthropod bites, porokeratosis, scabies, folliculitis, keratosis pilaris, multiple keratoacanthomas and lichen planus $[1,2,5]$.

The treatment is difficult as no therapy proved very effective. Topical and systemic retinoids, intradermal corticosteroids, UVB phototherapy, antihistamines, Allopurinol, Doxycycline, Metronidazole, Clindamycin can be used [1, 2, 13-15].
Delusional parasitosis (Ekbom syndrome, acarophobia, delusional infestations, Morgellons) is a monosymptomatic hypochondriacal psychosis characterized by the patient's false conviction that he is infested by parasites, insects or small animals. According to the Diagnostic and Statistical Manual of Mental Disorders, fifth edition (DSM-5), in order to be diagnosed with this condition patients must present a delusion that lasts at least one month, in the absence of any other psychiatric disorder, substance abuse or any organic cause and, if any other mood disorder is diagnosed, it must be of shorter duration than the delusion [16-18].

Patients with delusions of parasitosis most often address the dermatologist for their condition and only rarely the psychiatrist $[2,4,19]$.

With regard to the physical findings, some patients present no lesions while others show excoriations, ulcers, nodules or rashes produced by nails, tweezers, knives or other sharp objects in the pursuit for parasites $[2,4,17,19]$.

Before establishing the diagnosis of delusions of parasitosis a real infestation must be excluded.

The treatment is challenging and a close collaboration between the dermatologist and the psychiatrist is recommended $[2,4]$.

\section{CONCLUSION}

We report a rare case of Kyrle's disease in a patient whose only associated disorder is psychiatric, namely delusions of parasitosis. Kyrle' disease is very often associated with chronic kidney failure and/or diabetes mellitus and psychiatric disorders 
have not been reported in the medical literature as possible predisposing factors. In the case we are presenting the two afflictions occurred almost simultaneously. We believe that the presence of the two disorders in the same patient is coincidental. However, we hypothesize that the perforating disorder might have triggered the delusions of parasitosis due to the presence of pruritus. On the other hand, the constant excoriations and traumatizing of a skin prone to develop idiopathic Kyrle's disease in the attempt to remove the parasites prevented the lesions from healing. A close collaboration between the dermatologist and the psychiatrist is of paramount importance in resolving both the cutaneous disorder and the psychiatric disease.

Dermatozele perforante dobândite sunt un grup de afecțiuni cutanate rare caracterizate prin eliminarea transepidermică de material dermic modificat, cel mai frecvent asociate cu diabet zaharat şi insuficiență renală cronică. Delirul de parazitoză este o afecțiune psihiatrică în care pacienții au idei fixe, false că pielea lor este infestată de paraziți, în absența oricăror probe care să susțină afirmațiile lor.

Un pacient de sex masculin în vârstă de 69 de ani se adresează departamentului de dermatologie pentru o eruptie alcătuită din multiple papule cu aspect keratozic cu distribuție generalizată. Pacientul crede că leziunile sunt produse de mici paraziți care intră şi ies prin pielea sa. Examenul histopatologic a confirmat diagnosticul clinic de boala Kyrle. Examinarea psihatrică a stabilit diagnosticul de delir de parazitoză.

Acesta este primul caz raportat de boală Kyrle asociată cu delir de parazitoză. Nu există dovezi care să susțină ipoteza că delirul de parazitoză ar putea fi un factor predispozant pentru boala Kyrle. Cu toate acestea considerăm că dermatoza pruriginoasă ar fi putut declanşa delirul de parazitoză datorită pruritului asociat. Pe de altă parte, gratajul şi traumatizarea constantă a unui tegument predispus la dezvoltarea formei idiopatice a bolii Kyrle în incercarea de a îndepărta paraziții împiedică vindecarea completă a leziunilor cutanate.

Correspondence to: Sârbu Maria Isabela, MD, "Victor Babeş” Hospital of Infectious and Tropical Diseases,

Dermatology Department, Bucharest, Romania; Address: Sos. Mihai Bravu 281, $3^{\text {rd }}$ District, Bucharest, Romania Phone: 0040723391648

E-mail address: isabela_sarbu@yahoo.com

\section{REFERENCES}

1. SANDOZ A, KOENIG T, KUSNIR D, TAUSK FA. Psychocutaneous diseases. In: Fitzpatrick's dermatology in general medicine. McGraw Hill, New York. 2008: 912.

2. CHAI SUE LEE, JOHN YM KOO. Psychocutaneous Diseases. In: Dermatology. Elsevier, 2012: 127-29.

3. NAIR PA, JIVANI NB, DIWAN NG. Kyrle's disease in a patient of diabetes mellitus and chronic renal failure on dialysis. Journal of Family Medicine and Primary Care. 2015; 4(2):284-286.

4. MILlARD, LG, MILLARD J. Psychocutaneous disorders. Rook's Textbook of Dermatology, Eighth Edition, 2004: 1-55.

5. RUDIGER H. Psychiatric and neurologic diseases. In: Braun-Falco's dermatology. Heidelberg: Springer, $2009: 1193$.

6. ARORA K, HAJIRNIS KA, SAWANT S, SABNIS V, GAIKWARD N. Perforating disorders of the skin. Indian J Pathol Microbiol 2013; 56:355-8.

7. AZAD K, HAJIRNIS K, SAWANT S, SABNIS V. Kyrle's disease. Indian Dermatology Online Journal. 2013; 4(4):378-379.

8. SARAY Y, SEÇKIN D, BILEZIKÇI B. Acquired perforating dermatosis: clinicopathological features in twenty-two cases. J Eur Acad Dermatol Venereol. 2006; 20(6):679-88.

9. DETMAR M, RUSZCZAK Z, IMCKE E, STADLER R, ORFANOS CE. Kyrle disease in juvenile diabetes mellitus and chronic renal failure. Z Hautkr. 1990; 65(1):53-61.

10. KASIAKOU SK, PEPPAS G, KAPASKELIS AM, FALAGAS ME. Regression of skin lesions of Kyrle's disease with clindamycin: implications for an infectious component in the etiology of the disease. J Infect. 2005; 50(5):412-6.

11. WEINER J. Kyrle's Disease-hyperkeratosis follicularis et parafollicularis in cutem penetrans in siblings. Archives of Dermatology; 1967: 95(3):515.

12. SHIVAKUMAR V, OKADE R, RAJKUMAR V, PRATHIMA K. Familial Kyrle's disease: a case report. International Journal of Dermatology [serial online]. 2007; 46(7):770-771. Available from: Biomedical Reference Collection: Comprehensive, Ipswich, MA. 
13. SHIH CJ, TSAI TF, HUANG H, KO WC, HUNG CM. Kyrle's disease successfully treated with allopurinol. Int J Dermatol. 2011; 50(9):1170-2.

14. BAUMER FE, WOLTER M, MARSCH WC. The Kyrle disease entity and its therapeutic modification by acitretin (etretin). Z Hautkr. 1989; 64(4):286, 289-91.

15. PETROZZI JW, WARTHAN TL. Kyrle disease. Treatment with topically applied tretinoin. Arch Dermatol. 1974; 110(5):762-5.

16. EYLEM O. Delusional parasitosis with hyperthyroidism in an elderly woman: A case report. Journal of Medical Case Reports, 2013; 7(1), 17.

17. THAKKAR A. Delusional infestation: Are you being bugged? Clinical Ophthalmology (Auckland, N.Z.). 2015; 9:967-970.

18. AMERICAN PSYCHIATRIC ASSOCIATION. Diagnostic and statistical manual of mental disorders. $5^{\text {th }}$ ed. Arlington (VA): APA; 2013.

19. WONG JW, JOHN YMK. Delusions of parasitosis. Indian Journal of Dermatology 2013; 58: 49-52.

Received July 22, 2015 